\title{
Assessment of the Effectiveness of Ethical Corporate Governance in Corporate Decision-Making: A Grounded Theory Approach
}

\author{
Tony Ikechukwu Nwanji \\ Department of Accounting and Finance, \\ Landmark University, Omu Aran, Nigeria
}

Kerry E. Howell

Plymouth Business School, Plymouth University, UK

\section{Sainey Faye}

Department of Accounting and Finance, Buckinghamshire New University, Buckingham, UK

Dominic Z. Agba

Department of Economics, Landmark University, Omu Aran, Nigeria

\section{Sunday 0. Adewara}

Department of Economics, Landmark University, Omu Aran, Nigeria

\section{Adedoyin Ishola Lawal}

Department of Accounting and Finance, Landmark University, Omu Aran, Nigeria

\section{Adegbola Olubukola Otekunrin}

Department of Accounting and Finance, Landmark University, Omu Aran, Nigeria

\section{Frank D. Awonusi}

Department of Accounting and Finance, Landmark University, Omu Aran, Nigeria

\section{Damilola Felix Eluyela}

Department of Accounting and Finance, Landmark University, Omu Aran, Nigeria

\begin{abstract}
The article focused on the effectiveness of ethical corporate governance in decision making by the board of directors of top listed companies. Through the application of grounded theory approach in analysing data collected via the survey questionnaire, a substantive theory of ethical corporate governance is developed. The substantive theory developed is based on the shareholdership model of empowerment to create wealth and stakeholdership model of expectation to shared values. In term of ethical corporate governance, through organisations code of conduct and corporate social responsibility policies, companies can reach out to their broader stakeholdership groups through engagement with stakeholders. Such engagement is ongoing with shareholdership groups through boards' accountability to shareholders - the finding from this study further our understanding of ethical corporate governance issues.
\end{abstract}

Keywords: Corporate governance, shareholdership and stakeholdership models, business ethics, corporate social responsibility, grounded theory methods, qualitative research and substantive theory. 
Nwanji, T. I., Howell, K. E., Faye, S., Agba, D. Z., Adewara, S. O., Lawal, A. I., Otekunrin, A. O., Awonusi, F. D., \& Eluyela, D. F. (2019). Assessment of the Effectiveness of Ethical Corporate Governance in Corporate Decision-Making: A Grounded Theory Approach. Archives of Business Research, 7(1), 147-168.

\section{INTRODUCTION}

The primary aim of this article is to demonstrate how grounded theory methodology was applied to the study of corporate governance issues, particularly the practice of top management of corporations. The article employs grounded theory methodology in analysing data collected through Company Secretaries on the ethical corporate governance practices of boards of directors of FTSE-100 companies in the UK. The study argues that the objective of grounded theory is to attempt to understand reality through social constructions. It also tries to achieve objectivity through recognising the subjectivity of the researcher(s) and research regarding their interpretative nature (Howell, 2000). The underlying theme of grounded theory is the development of theory from data systematically obtained from social research. While many qualitative studies of organisation and management have used the grounded theory methodology approach, few methodological references use the grounded theory approach in the study of ethical corporate governance practices of the board of directors. Hence approach will provide insights and understanding of corporate governance systems, particularly the area of the interface between business ethics and corporate objectives. Corporate governance is an area that has been growing steadily in importance in the last decade. (Nwanji and Howell, 2007a, 2007b; Nwagbara and Ugwoji, 2015). The Cadbury report of 1992 on the financial aspects of corporate governance in the UK laid the foundations of the current corporate governance regulatory framework in the UK. Indeed, the Cadbury report's influence has not been limited to the UK, countries all over the world have incorporated its main principles into their corporate governance codes. Corporate governance aims to ensure that the boards of directors carry out their duties correctly. The guidelines direct the boards and management of firms to act to utilise the assets of the company to increase the returns to the firm's shareholders.

The questions to answer in this study are as follows (1) how effective is ethical corporate governance in corporate decision making (2) is there a trade-off between business ethics and corporate objectives? (3) Does an increased emphasis on business ethics affect enterprises? In line with the research questions above, the primary objective of the study is to assess the effectiveness of ethical corporate governance on corporate decision making. This objective will be achieved through the application of grounded theory methodology in the context of the ethical behaviour of boards of directors and top management of public companies in the UK.

\section{REVIEWING THE LITERATURE}

The current updated UK Corporate Governance Code (the Code 2016:1). states that "the purpose of corporate governance is to facilitate effective, entrepreneurial and prudent management that can deliver the long-term success of the company." The Cadbury Committee Report (1992), is the first version of the UK Corporate Governance Code. (FRC Financial Reporting Council 2014). Its paragraph 2.5 is still the classic definition of the context of the Code:

"Corporate governance is the system by which companies are directed and controlled. Boards of directors are responsible for the governance of their companies. The shareholders' role in governance is to appoint the directors and the auditors and to satisfy themselves that an appropriate governance structure is in place. The responsibilities of the board include setting the company's strategic aims, providing the leadership to put them into effect, supervising the management of the business and reporting to shareholders on their stewardship. The board's actions are subject to laws, regulations and the shareholders in general meeting." 
Corporate governance also refers to the procedures and instruments that the owners and interest groups of a company use to influence and monitor management decisions and processes. It is widely regarded as the evaluation of the performance of the executive directors of the company by, or for the company's stakeholders' groups. According to Nwanji and Howell (2005:1)

"Corporate governance aims to ensure that the boards of directors do their jobs properly. It also protects shareholders' right, enhances disclosure and transparency, facilitates the effective functioning of the board and provides an adequate legal and regulatory enforcement framework. It addresses the agency problem through a mix of the company law, stock exchange listing rules and self-regulatory Codes."

Corporate governance is also about guiding management through managing the affairs of the company which leads to the achievement of the companies' objectives whether those objectives are Shareholdership or Stakeholdership ones as far as management kept within the rule of the games (Friedman, 1970).

\section{UK Corporate Governance Code}

In the UK, the collapse of four companies in the 1990s, (Maxwell Corporation, Polly Peck, Bank of Credit and Commerce International BCCI, and the Barings Bank) led to the setting up of three major committees to investigate the effectiveness of corporate governance practices. Since then there have been other reports on corporate governance following any significant corporate collapse. (Fig. A) Below shows the major corporate failures leading to the setting up of committee reports on different areas of corporate governance issues. The first three committees' reports resulted in the first Combined Code on corporate governance in 1998, which was updated in 2003 following the recommendations of the Higgs and Smith Reports after the collapse of Enron and WorldCom in the USA in 2001.The Fig.(A) below shows that corporate governance regulations, codes and reports only react after major corporate collapse regather than proactive to prevent corporate failures. (Chowdhury, et al., 2018).

The events on corporations (see, Fig. A) below has led to increased research on corporate governance systems in the UK, US, EU and many other countries. There are now at least 40 countries with published corporate governance codes (Cadbury,2002). Researchers employ database analysis or, less frequently, survey questionnaires and take the form of either crosssectional or event-study research designs (Zajac and Westphal, 1996a, 1996b; Sephered, 1999), have all worked in this area of corporate governance research. Cook and Deakin, (1999) noted that quantitative methodologies had dominated the study on board structure. They stated that a quantitative analysis of the relationship between various aspects of board structure and the Chief Executive Officer (CEO), management power balance assumes an underlying agency-type relationship. The Hampel Committee, (1998:25) stated, "Corporate governance must contribute both to business prosperity and accountability. Liao, 2010; Cheer et al., 2015; Ogbu, 2015). The UK Combined Codes of are reviewed by the Financial Reporting Council every two years and since the Global Banking and Financial meltdown of 2009-2011, there has been a review of what is now known as UK Corporate Governance Code in (FRC, 2012, 2014 and 2016). 


\section{Corporate Collapse and Committee Reviews in the UK}

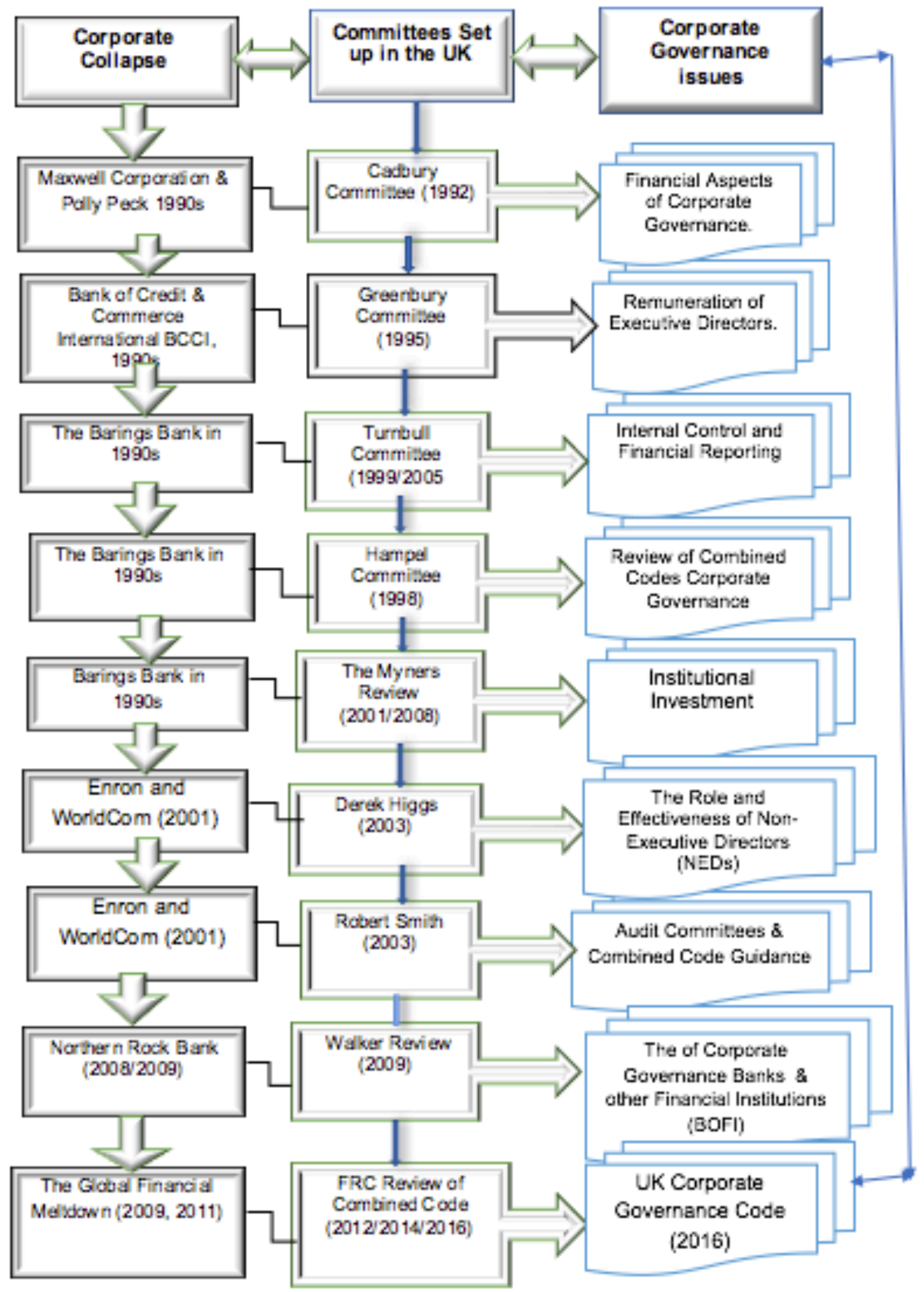

Fig. (A): Source: Authors (2018)

Showing the pattern of corporate collapse and committee reports resulting in corporate governance issues/regulations in the UK from 1990 to 2016.

The Institute of Directors (IOD) has ongoing research (Volpin, and Clare, 2015) on The Great Governance Debate - Towards a Good Governance that focused on FTSE-100 (The top UK companies on the London Stock-Exchange) The Institute of Chartered Secretaries and 
Administrators (ICSA UK) has its Good Corporate Governance that supports the Board of Directors of top companies in the UK. All the UK Six Institute Chartered Accountants are continually supporting and funding research on corporate governance (ICAEW, ACCA, CIMA, ICAS, CIPFA, ICANI). We can say that the UK corporate governance leads the World in corporate governance research.

\section{Theoretical Framework on Corporate Governance}

The four major corporate governance models are outlined below to illustrate the effects of each model about the shareholdership and stakeholdership models of corporate governance. (Fera, 1997; Abor, 2007; Nwanji and Howell, 2007b; Roy, 2015; Mitlak, 2016; Patel, 2018;)

i. The Principal-Agent or Finance Model, (Jensen and Meckling, 1976; Manne, 1965), states that the purpose of the corporation is the maximisation of shareholders profits, as the shareholders are the owners of the corporations and bear the highest risks. However, this model creates an agency problem.

ii. The Myopic Market Model, (Charkham, 1989; Sykes, 1994), also states that the purpose of the firm is the maximisation of shareholders profits. However, the model is concerned with the pursuit of short-term market value at the expense of long-run goals.

iii. Executive Power Model, (Hutton, 1995; Kay and Silberston, 1995), is concerned with the maximisation of corporate wealth but recognises the problem of the abuse of executive power for managers' self-interest.

iv. The Stakeholder model (Freeman, 1984; Blair, 1985), leads to the maximisation of stakeholders' wealth but also creates an absence of stakeholders' involvement. (Jensen, 2001).

The first two can be grouped into the shareholdership model and the other two make up the stakeholdership model. The two shareholdership model (the principal-agent or finance model, and myopic market model) are reviewed below to demonstrate why the shareholdership model of corporate governance is claimed to be the best way of meeting corporate business objectives to maximise shareholders' wealth. The current regulatory framework in the UK is derived from the shareholdership approach to corporate governance. The principal-agent or finance model (Manne, 1965; Jensen and Meckling, 1976; Baiman, 1990; Shleifer and Vishny, 1997; Dalton et al., 2003) states that the purpose of the corporation is the maximization of shareholders' profits as the shareholders are the owners of the corporations and bear the highest risks. This model is seen as the dominant view of the corporation. (Fama and Jensen, 1983a, 1983b).Keasey et al., (1997) state that the model sees a firm's existing corporate governance arrangements as the outcome of a bargaining process, which has been freely entered by corporate insiders and outsiders. If difficulties of corporate governance are not resolved these market failures in turn also have implications for corporate finance in that equity will be costly and often subject to quantitative restrictions (Davis, 2000; Jalan, 2006).

The best way to reflect different preferences and to discover optimum methods of fulfilling shared preferences are to make the objectives of corporate governance clear and to subject the mechanisms for achieving them to free competition in the marketplace (Sternberg 2001). For example, the introduction of a voluntary code such as Cadbury report,(Sun 2002; Letza et al., 2004; Sternberg, 2004). Berle and Means (1932:313) called for the separation of ownership and control as a necessary explanation for corporate behaviour and the problems confronting owners (fragmented and dispersed shareholders) who attempt to exert their rights over the managers who have gained control in the 'modern' corporation. The Authors stated that:

"The rise of the modern corporation has brought a concentration of economic power which can compete on equal terms with the modern state - economic power versus political power, each strong in its field. The state seeks in some 
aspects to regulate the corporation, while the corporation, steadily becoming more powerful, makes every effort to avoid such regulation."

Kirkbride and Letza, (2005a, 2005b) stated that: in the UK, there has been a debate over the role of the independent non-executive directors, with that debate resulting in changes to a revised Code applicable to companies report.

\section{Business Ethics}

Business ethics could be defined as self-critical, well-intended, legitimate and discourse-based business criticism. In contrast to legitimate and conscience criticism and as less formal and public, as less emotional and private business criticism and with integrating, productive and conflict-resolving functions in each stakeholder context.

"Business ethics in its broadest sense can be defined as being the study of the moral justification of economic systems at both the national and international scale. It was identified as a subject of study and research in the 1970s, and a good deal of work has focused on the structures, responsibilities, and activities of modem day corporations." (Institute of Business Ethics 2001).

The literature on business ethics about corporate governance is quite extensive. There are those who argue that business ethics is not suitable for business or that it is not the responsibility of corporations to act ethically and have moral values. They claim that managers conduct business better if they put ethical concerns aside and single-mindedly attend to the pursuit of profits. Adam Smith's Wealth of Nations (1776) stressed the decisive role that individual initiative and the desire for profits play in economic progress. Smith's position was that business should be conducted outside ethics. According to this view, commerce is an independent sector of human activity governed by its own rules and standards. Left to themselves and allowed to operate freely, directors will produce maximum benefit for shareholders and society. To impose ethical norms and conduct is doomed for failure and will only impede economic creativity and progress (Green 1994; Greenwood 2000). This view was taken up in the modern business ethics by Friedman and others. Friedman (1970:7) view was that the only Social responsibility of business is to increase its profits.

"In a free society, there is one and only one social responsibility of business - to use its resources and engage in activities designed to increase its profits so long as it stays within the rules of the game which is to say engages in open and free competition without deception or fraud,"

On the other hand, Sternberg (2000: 8) did not agree with Friedman's view above when the author said that:

"Business ethics is not a dispensable option; the choice facing management is not whether to confront ethical concerns but how. It provides a greater awareness of what is important in business activities and can, therefore, improve business performances. If management ignores the demands of business ethics or gets them wrong, they will be unlikely to maximise their organisation's long-term stakeholders'values."

On the question of the effect of business ethics on corporate objectives, much research has been conducted on corporate social responsibility (CSR). Indeed, the starting point for this study could be Friedman, (1970) claim that the modern corporation has no social responsibility to the public, only fiduciary duties to its owners(shareholders). Economists, 
philosophers, business ethicists and academia, have since debated Friedman's famous statement over the last 48 years. Furthermore, stakeholdership model concerns the ethical and moral duties of corporations to all their stakeholders as well as the interest of their shareholders. Much research has been conducted on the link between stakeholdership theory and corporate governance issues over the years. (Freeman, 1984; Blair, 1995; Howell and Letza, 2000; Phillips, 2003).

\section{RESEARCH QUESTIONS AND RESEARCH PARADIGM}

The survey questionnaire was based on the research questions on the ethical corporate governance practice of the board under study. These are the research questions that the article sets out to investigate through the analysis of the results of the data from the survey questionnaire.

1. Is there a trade-off between business ethics and corporate objective?

2. Is the purpose of corporation ethical?

3. Does an increased emphasis on business ethics affect enterprise?

The research paradigm for this study is critical theory, the ontology is historical realism, and through this, the thesis objective is to investigate the differences between directors' mindsets and reality. The ontology is that there is an interaction/limited difference between the two. (Denzin and Lincoln, 2002, 2013; Guba and Lincoln, 2002).

The study explores these links between the corporation as ethical and governing actions as ethical, examining the difference between the two, and focusing on boards of directors of top companies in the UK. The study takes ethical, theoretical perspectives of corporate governance to decision-making processes and investigates the question of whether the governing actions/ behaviour of boards of directors and their company is ethical?

\section{GROUNDED THEORY METHODOLOGY}

Grounded theory is intended as a methodology for developing theory that is grounded in data, which is systematically gathered and analysed. The theory evolves during the research process and is a product of the continuous interplay between analysis and data collection. It requires the recognition that knowledge is actively constructed with meanings of existence relevant to an experiential world. Grounded theory as a methodology was first developed by Glaser and Strauss, (1967) for the study of sociology. Since then it has been used for qualitative studies in organization and management, education, corporate governance, nursing and political science. (Strauss, 1987; Glaser, 1992, 1998; Charmaz,2000, 2014; Locke,2001; Howell, 2003; 2013; Nwanji and Howell, 2005, 2007b; John, 2013). Grounded theory methodology offers a comprehensive and systematic framework for inductively building of theory. The research design in this study is a survey questionnaire, and the instrument of data collection is a questionnaire. The survey was conducted with Company Secretaries from top companies in the UK, to ascertain their views on the ethical corporate governance practices of their boards of directors. The questionnaire was made up of ten statements with five possible answers in each statement requiring the respondents to opt for one response based on the Likert format of questionnaire design, with varying degrees of agreements to disagreements.

\section{RESEARCH METHODS SURVEY}

As Goulding, (2002: 42) points out: "Knowledge and theory are used as if they were another informant, for, without this grounding in existing knowledge, pattern recognition would be limited to the obvious and the superficial, depriving the analyst of the conceptual leverage from which to commence theorising." 
Nwanji, T. I., Howell, K. E., Faye, S., Agba, D. Z., Adewara, S. O., Lawal, A. I., Otekunrin, A. O., Awonusi, F. D., \& Eluyela, D. F. (2019). Assessment of the Effectiveness of Ethical Corporate Governance in Corporate Decision-Making: A Grounded Theory Approach. Archives of Business Research, $7(1), 147-168$

This is an important point, as the ultimate goal of using grounded theory for this study is to develop a substantive theory of ethical corporate governance. Qualitative research is considered as being valid according to quasi-positivistic criteria within the field of management.

Questionnaire format: The questionnaire was developed based on the ethical perspective on corporate governance about boards of directors' behaviours when deciding on business ethics. It contains ten statements with each statement focusing on the corporate governance practices of boards of directors. The questionnaire requires participants to pick one answer out of five based on the Likert scale method where (SA) represents strongly agree, (A) represents agree, (NV) represents no-view, (D) represents disagree and (SD) represents strongly disagree.

The Statement of the Survey Questionnaire

\begin{tabular}{|l|l|l|l|l|r|}
\hline KEY: & Strongly Agree, (SA) & Agree (A) & No View (NV) & Disagree (D) & Strongly Disagree (SD) \\
\hline
\end{tabular}

\begin{tabular}{|c|c|c|c|c|c|c|c|}
\hline NO & STATEMENTS & SA & A & NV & D & SD & Total \\
\hline 1 & $\begin{array}{l}\text { Your Board of Directors have made changes to enhance their Governance } \\
\text { practices since the introduction of the Combined Code }\end{array}$ & 43 & 16 & 4 & 3 & 0 & 66 \\
\hline 2 & $\begin{array}{l}\text { Your Board has a Committee responsible for a review of its Governance } \\
\text { practices. }\end{array}$ & 42 & 18 & 3 & 2 & 1 & 66 \\
\hline 3 & $\begin{array}{l}\text { Your organisation's Corporate Governance practices compare actively with } \\
\text { ICSA Good Governance Best Practices }\end{array}$ & 46 & 19 & 1 & 0 & 0 & 66 \\
\hline 4 & $\begin{array}{l}\text { Your organisation's Governance practices compare actively with the Combined } \\
\text { Code of Best Practices. }\end{array}$ & 33 & 29 & 2 & 2 & 0 & 66 \\
\hline 5 & $\begin{array}{l}\text { Your company has consistently complied with the Combined Code on } \\
\text { Corporate Governance over the past five years }\end{array}$ & 50 & 14 & 0 & 2 & 0 & 66 \\
\hline 6 & $\begin{array}{l}\text { As a Company Secretary, you are responsible for risk management in your } \\
\text { organisation. }\end{array}$ & 38 & 23 & 3 & 2 & 0 & 66 \\
\hline 7 & $\begin{array}{l}\text { Your organisational code is seen as a statement of the organisation's ethical } \\
\text { values }\end{array}$ & 38 & 25 & 2 & 1 & 0 & 66 \\
\hline 8 & I consider my organisation to have high ethical values about its stakeholders. & 32 & 20 & 7 & 5 & 2 & 66 \\
\hline 9 & $\begin{array}{l}\text { Your board considers Business Ethics when setting the company's business } \\
\text { objectives. }\end{array}$ & 30 & 24 & 10 & 2 & 0 & 66 \\
\hline 10 & $\begin{array}{l}\text { Your organisation's Corporate Governance practices focus on meeting the } \\
\text { business objectives of maximising shareholders wealth. }\end{array}$ & 40 & 21 & 4 & 1 & 0 & 66 \\
\hline 11 & $\begin{array}{l}\text { The financial meltdown indicates that reliable and effective Corporate } \\
\text { Governance is required if companies are to meet their shareholders' needs. }\end{array}$ & 46 & 13 & 5 & 1 & 0 & 66 \\
\hline 12 & $\begin{array}{l}\text { Good practice of Corporate Social Responsibility (CSR) that takes the needs of } \\
\text { a company's stakeholder groups into consideration creates }\end{array}$ & 40 & 20 & 3 & 2 & 1 & 66 \\
\hline
\end{tabular}

Table (1): Source: Authors' Fieldwork (2018):

Survey of chartered secretaries on the regarding the corporate governance practices of Their organisations based on Likert Scale 1- 5

\section{DATA ANALYSIS}

The analysis of the results of the survey used grounded theory coding procedures to develop categories from the data. Glaser (1992) defined categories as an area of higher order concepts. They have much more full explanatory power and pull together all the identified ideas into a theoretical framework. The analysis is based on the results of the respondents on each of the ten statements of the questionnaire using a Likert scale to identify categories. The results of the survey questionnaire were converted into a table based on the Likert scale format shown in the (Table 2) below. As can be seen,66 respondents stated that they work for top companies which indicated that $66 \%$ of company secretaries from the top UK companies took part in the survey. (Harvey, 2012; MENA Report, 2016). A summary of (Table 2) below shows that most of the respondents overall, either strongly-agree or agree with each of the ten statements on the 
survey. This is not surprising as compliance with the Combined Code provisions is required for top companies under the Listing Rules of the London Stock Exchange. It is a pre-condition for listing on the Exchange that boards of directors of top companies must state in their Annual Reports and Accounts how their companies have complied with the Combined Code provisions or explain their reasons for non-compliance, (Comply or Explain Rule). The other factor is that compliance with the Combined Code's reviewed 2012, requirements on corporate governance are viewed not only as an indication that boards of directors are meeting the needs of their shareholders but also as an evaluation of the board's performances. There is also the pressure from increasing shareholders activism particularly the Institutional Shareholders, which forces the board to provide more and better information on how it has managed the affairs of the company.

Survey of Companies in the UK

\begin{tabular}{|c|c|c|c|c|c|c|c|c|c|c|}
\hline Statements & $\begin{array}{l}\text { Strongly } \\
\text { Agree }\end{array}$ & \multicolumn{3}{|c|}{ Agree } & \multicolumn{2}{c|}{ No View } & \multicolumn{2}{c|}{ Disagree } & \multicolumn{2}{c|}{$\begin{array}{l}\text { Strongly } \\
\text { Disagree }\end{array}$} \\
\hline 1 & 43 & $65 \%$ & 16 & $24 \%$ & 4 & $6 \%$ & 3 & $5 \%$ & 0 & 0 \\
\hline 2 & 42 & $64 \%$ & 18 & $27 \%$ & 3 & $5 \%$ & 2 & $3 \%$ & 1 & $1 \%$ \\
\hline 3 & 46 & $70 \%$ & 19 & $29 \%$ & 1 & $1 \%$ & 0 & 0 & 0 & 0 \\
\hline 4 & 33 & $50 \%$ & 29 & $44 \%$ & 2 & $3 \%$ & 2 & $3 \%$ & 0 & 0 \\
\hline 5 & 50 & $76 \%$ & 14 & $21 \%$ & 0 & 0 & 2 & $3 \%$ & 0 & 0 \\
\hline 6 & 38 & $58 \%$ & 23 & $35 \%$ & 3 & $4 \%$ & 2 & $3 \%$ & 0 & 0 \\
\hline 7 & 38 & $58 \%$ & 25 & $38 \%$ & 2 & $3 \%$ & 1 & $1 \%$ & 0 & 0 \\
\hline 8 & 32 & $48 \%$ & 20 & $30 \%$ & 7 & $11 \%$ & 5 & $8 \%$ & 2 & $3 \%$ \\
\hline 9 & 30 & $46 \%$ & 24 & $36 \%$ & 10 & $15 \%$ & 2 & $3 \%$ & 0 & 0 \\
\hline 10 & 40 & $61 \%$ & 21 & $32 \%$ & 4 & $6 \%$ & 1 & $1 \%$ & 0 & 0 \\
\hline 11 & 46 & $70 \%$ & 13 & $20 \%$ & 5 & $8 \%$ & 1 & $1 \%$ & 0 & 0 \\
\hline 12 & 40 & $60 \%$ & 20 & $30 \%$ & 3 & $5 \%$ & 2 & $3 \%$ & 1 & $2 \%$ \\
\hline
\end{tabular}

Table (2): Note: (The percentages here are rounded to the whole number in each statement). The summary of data collected for this study.

\section{Open Coding Categories}

To identify categories tables (2) above is constructed into bar chart models with each model focusing on the results of each statement from the survey questionnaire. Using the grounded theory coding procedures, we develop categories that are common to each other from the survey data. This is shown below in (Fig. 1 to12). The charts show the analysis of the respondents' views based on Likert scale 1-5. This process provides the basis for generating an emergent set of categories and their properties that fit and are relevant for integrating theory. According to Glaser (1978:56) "to achieve the goal the analyst begins with opening coding."

\section{Governance Practice}

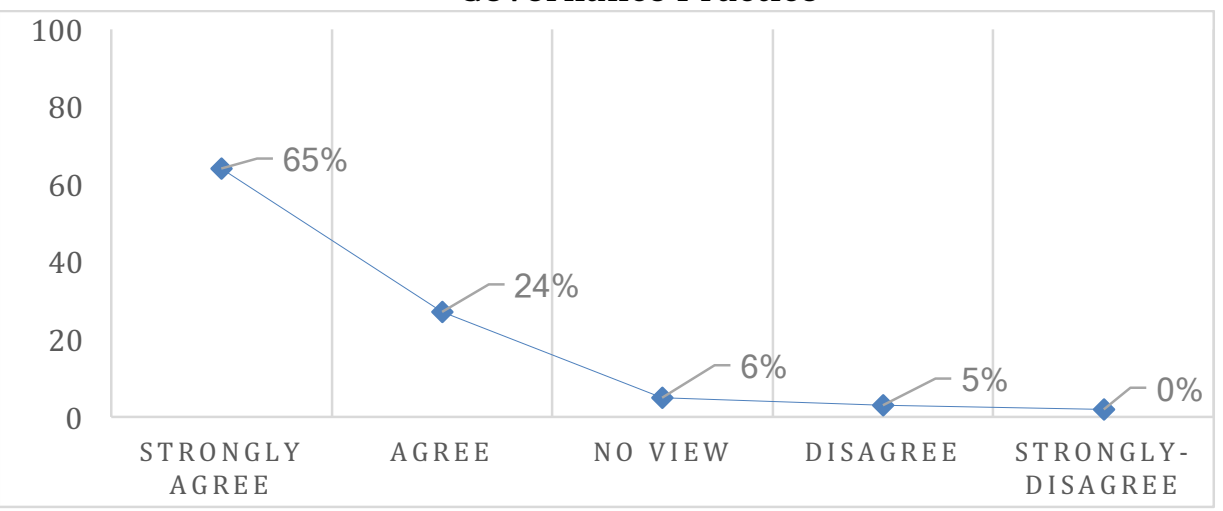

Fig. (1): Statement 1: The Board of Directors have made changes to enhance their Governance practices since the introduction of the New Combined Code: Respondents answers on a scale of 1-5 
Statement (1):As can be seen from (fig. 1), above, $65 \%$ of the respondents strongly agree that their boards of directors made some changes to their governance practices as a result of the Combined Code on corporate governance and other financial regulations, with $24 \%$ of the respondents stating that their boards made some changes to their governance practices. $6 \%$ of the respondents had no-view, with only $5 \%$ disagreeing with the statement (1). The result indicates that boards of directors take their governance practices as an essential part of providing shareholders with information on how the board has managed the affairs of the company. According to the principles of corporate governance published by the (OECD, 2004), a company's corporate governance framework should ensure the strategic guidance of the company, the active monitoring of management by the board and the board's accountability to the company and its shareholders. The high number of agreements with the statement (1) further confirmed the views that most corporations expect their boards of directors to comply with the combined code on good corporate governance provisions as part of their accountability to shareholdership and other stakeholdership groups of the company. (Bar, 2017; Evans, 2016).

Statement (2) of the survey questionnaire also focused on the governance practices of boards of directors in which the participants were asked if their companies' boards of directors appointed committees to help them with evaluation of their performances. Shown in (Fig.2) below, $64 \%$ of the respondents strongly agree that such committees exist in their organisation, and $27 \%$ agree with the statement while only $5 \%$ had no-view with another 3\% disagreeing with the statement. A further $2 \%$ of the respondents strongly disagree with the statement(2). Board committees advise the board on the efficient and effective implementation of strategies which can often be the most difficult and challenging aspect of the entire process.

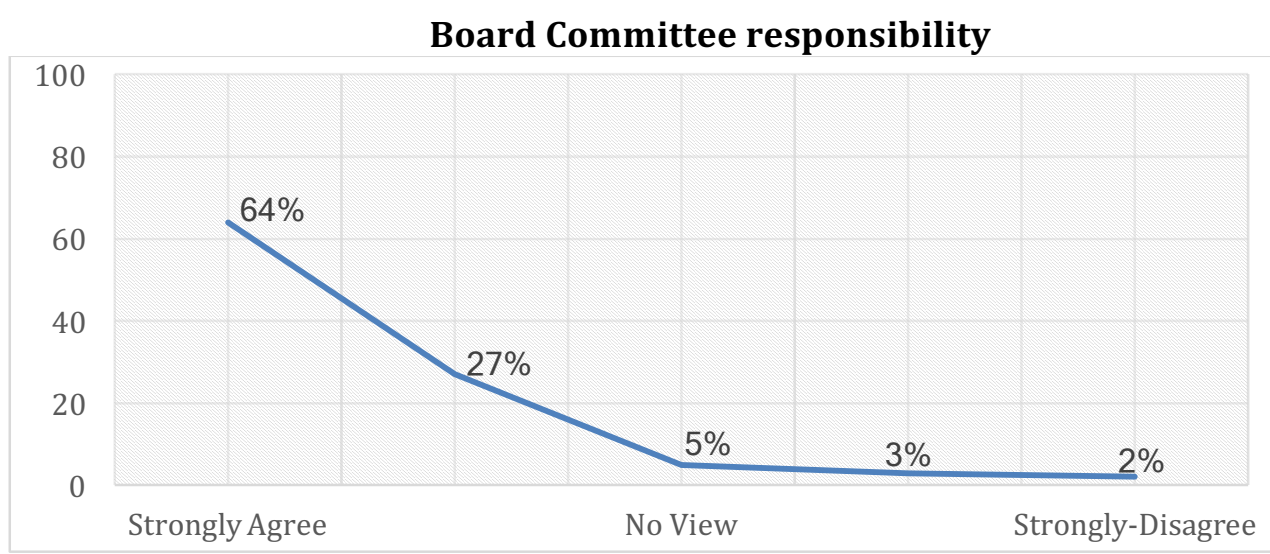

Fig.(2): on Statement (2) of Board Committee responsible for a review of its governance practices.

PricewaterhouseCoopers'Shareholder Questions 2003' claimed that:

"The governance framework should not be a "straight jacket" - it should allow the company to be responsive to the increasingly fast-changing commercial environment. The aim is to create a long-term strategy, which will result in the creation of greater value for shareholders, alongside associated benefits for employees, customers, and other stakeholders."(PWC, 2003:8)

Good practices for an active board include:

- Reviewing and challenging management's strategic options

- Thinking sufficiently widely when reviewing strategy proposals

- Taking steps to reduce risks in planning mergers or acquisitions 
Statement (3) of the survey relates to the issue of compliance with the Combined Code and other corporate governance regulations. On this statement,70\%of the respondents strongly agree and 29\% respectively that the corporate governance practices of their organisation meet the standard of the ICSA Good Governance Practices. Moreover, only 1\% of the respondents had no-view, while none of them disagreed or strongly disagreed with the statement. The result is shown in (Fig. 3) below. The institute Chartered Secretaries and Administrators (ICSA) have a range of programmes to suit those requirements of the Combined Code, namely: (i) Whole Board Evaluation, (ii) Evaluation of Principal Committees and (iii) An Evaluation of Individual Director. Through its work and its members, the Institute has direct knowledge, current experience and an instructive understanding of the operation of boards and the challenges facing directors. (see ICSA, 2012; Yahaya, 2016)

Governance Practices compare with Best Practices.

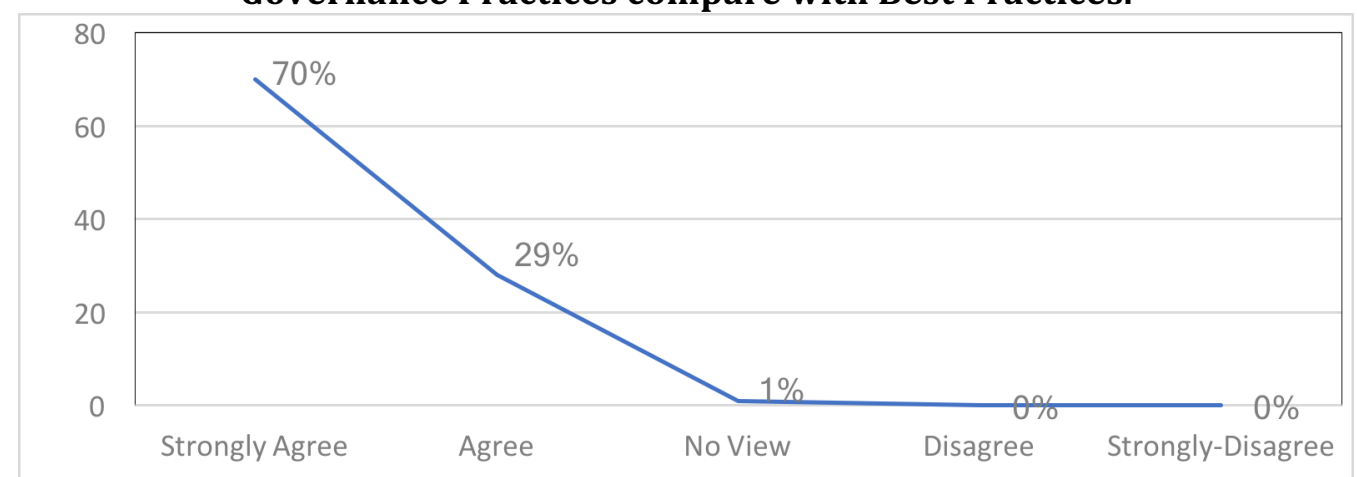

Fig.(3): on Statement 3: The Organisation's Governance Practices compare actively with ICSA Good Governance Best Practices.

Statement (4) of the survey focuses on compliance with the Combined Code and other corporate governance regulations. The respondents were asked if their companies' governance practices sharply compared with the Combined Code best practices. The result of the survey confirmed that the corporate governance practices of the boards of directors of top companies measure up to the standard of the Combined Code of Best Practices. In this case, 75\% and 19\% of the respondents strongly agree or agree respectively with statement 4 . Only $3 \%$ of them had no-view with another $3 \%$ disagreeing with the statement none strongly disagree, and this can be seen in(Fig.4) below. The Combined Code (2003:1) states that:

"The board's role is to provide entrepreneurial leadership of the company within a framework of prudent and effective controls which enables risk to be assessed and managed. The board should set the company's strategic aims, ensure that the necessary financial and human resources are in place for the company to meet its objectives and review management performance.

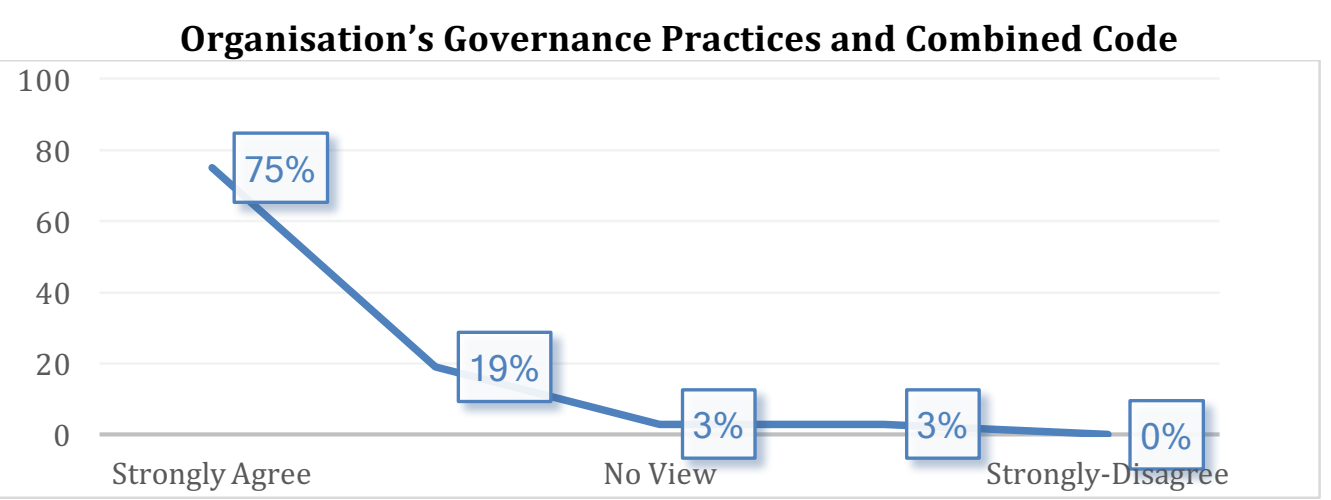

Fig. (4) Statement 4 on The Organisation's Governance Practices compare actively with the Combined Code of Best Practices. 
Statement (5) on compliance with the Combined Code and other corporate governance regulations, $76 \%$ of the respondents strongly agree that their company has consistently complied with the Code for the past years, with just $21 \%$ admitting to this and only $3 \%$ disagreed. The result of the analysis is represented in figure (5) below

No company can expect to manage risk efficiently without first creating a primary system of internal controls, designed to safeguard shareholders' investment and the company's assets. The controls need to consider the risk of non-compliance with regulations affecting the industry. (PricewaterhouseCoopers, 2003).

The combined code of corporate governance (2012) had clear ethical dimensions when it stated: that "...designed to achieve the necessary high standards of corporate behavior." If corporate governance is to contribute to business prosperity and accountability, then a company will need effective internal control, financial reporting and risk management systems in which an independent audit committee will help the board to achieve. (Volpin, and Clare, 2015).

\section{Company Complied with the Combined Code}

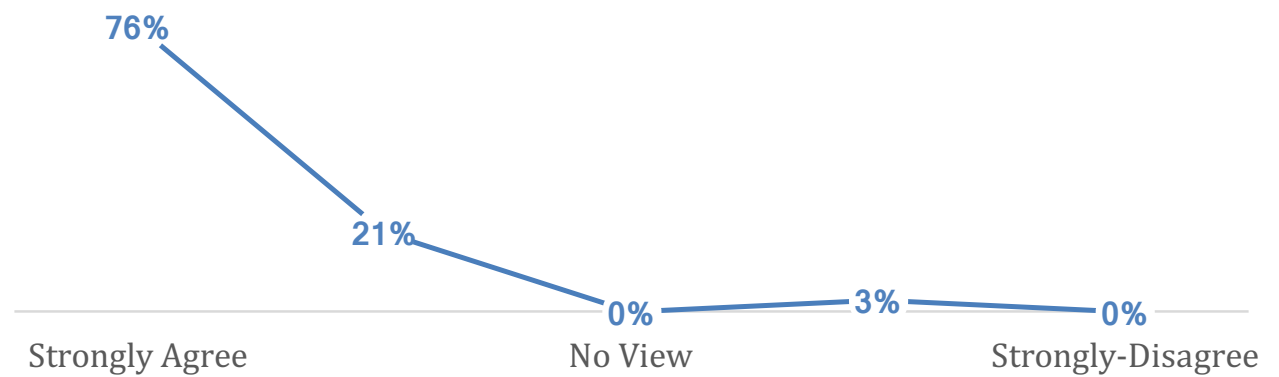

Fig. (5): Statement 5: on the company has consistently complied with the Combined Code on corporate governance over the past 10 years.

Statement (6) below on risk management and internal control, 58\% of the respondents strongly agree that they are responsible for the risk management of their organizations, while $35 \%$ said that they play some part on risk management of their companies. However, $4 \%$ and $3 \%$ respectively had no-view or disagree that they play any role in the risk management and internal control of their organizations. The result represented in figure (6) below. In most top companies, risk management is by usually overseen by a board member of management with the company secretary providing advice or technical support to the director as required.

Management should identify and evaluate the risks faced by the company for consideration by the board and design, operate and monitor a suitable system of internal control which implements the policies adopted by the board." (Turnbull Report, 2005).

Corporate governance is seen as a risk, which boards of directors should manage well to meet the business and financial objectives of their companies. The image and reputation of the organization to its broader stakeholdership groups can affect the maximization of shareholdership values if they are not handled in a better way. Regarding stakeholdership values, boards of directors would project the companies' image through corporate codes that the board, management and staff should observe. Decisions that take business ethics and moral values into consideration can significantly improve the company's standing to both shareholdership and stakeholdership groups. Unethical behavior by directors could lead to 
financial risk as the cases of Enron and WorldCom in 2001 have shown. (Combined Code, 2003).

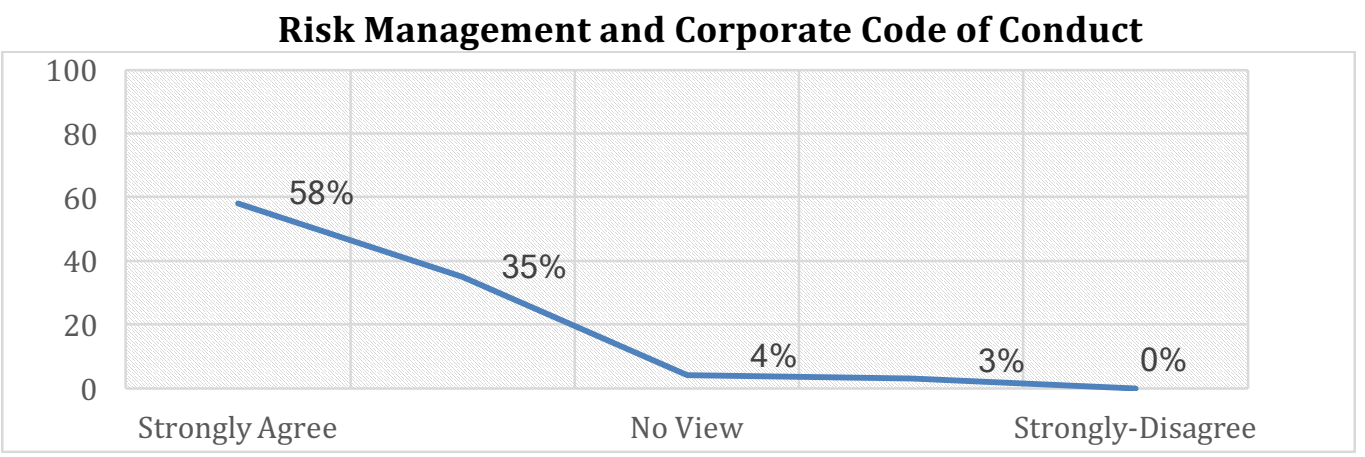

Fig. (6): Statements 6: on Company Secretary you are responsible for risk management and internal control in your Organisation.

Statement (7): on the organisational code is an essential part of managing the affairs of the company. The organisational code of conduct clarifies the policy of a company. It shows what the company expects from its management and employees. The reflection on values and norms will also help to reduce inconsistencies in the policy of the company. As shown in (Fig. 7), $(58 \%)$ of the respondents strongly agree that organisational code is seen as a statement of its ethical values, and a further (38\%) agree with this statement. Fewer than (5\%) of the respondents had no-views or disagree that their company's code is its ethical values.

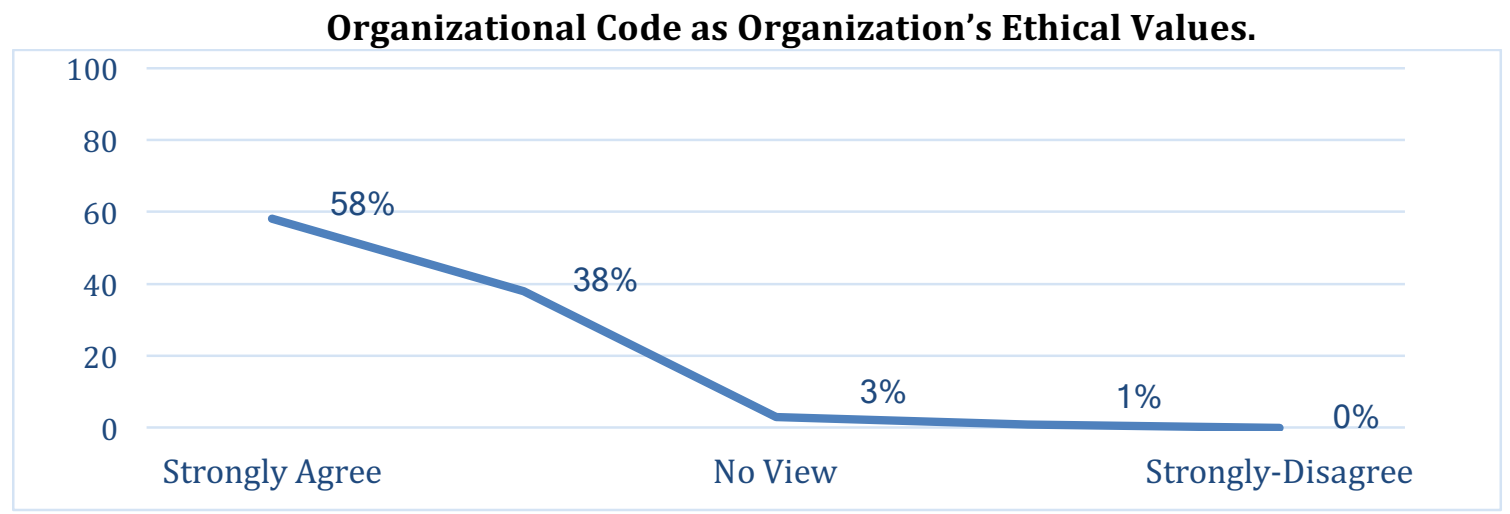

Fig. (7): Statement 7: on the Organizational Code is seen as a statement of the Organization's Ethical Values.

This may indicate the importance a multinational corporation attaches to the development of its code of ethics, as the code is the means of expression of the corporation's ethical values to the world. It can be seen from the analysis of the result that having a code of ethics is considered a good corporate governance practice. Codes should not develop merely as a reaction to a reputation crisis. With proper leadership and support from the board, the staff at all levels and all jurisdictions of the corporation should be involved in both the content and implementation of a corporate code to be effective. Pressures on boards of directors to take corporate code conduct seriously have grown in the past 26 years since the Cadbury Report of 1992.

Statement (8) on the organisation's ethical values about its stakeholdership groups. As indicated from the survey result represented in (Fig.8)below, only (48\%) of the respondents strongly agree, with a further (30\%) acknowledging that their organisations have higher ethical values about the needs of its different stakeholdership groups. However, (11\%) of the respondents had no-view, while (8\%) disagree and a further (3\%) strongly disagree. 


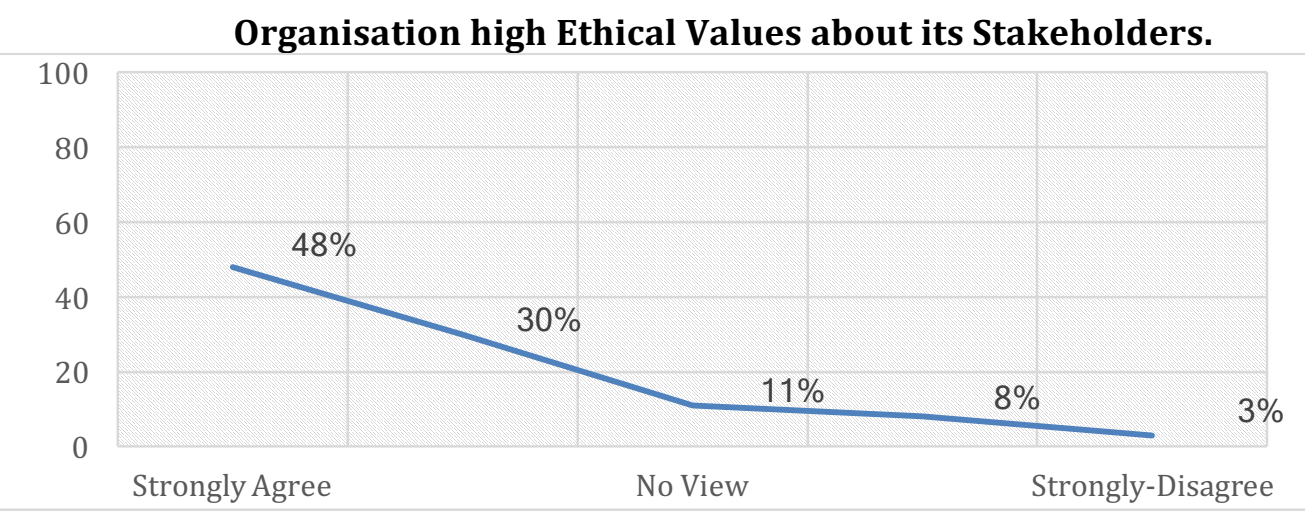

Fig. (8): Statement 8: on I consider my Organisation to have high Ethical Values about its Stakeholders.

Statement (9) of the survey results focused on business ethics and corporate objectives and it highlights strategic issues, which boards of directors may wish to address. The literature shows that some board members appear not to give dedicated support to business ethics when setting the company's corporate objectives. As the results of the analysis shown in (Fig. 9)below, (46\%) of the respondents strongly agree, while a further (36\%) agree that their board takes business ethics into accounts when setting the business objectives of the company. $(15 \%)$ of the respondents expressed no-views on the matter while $3 \%$ disagree and none strongly disagree.

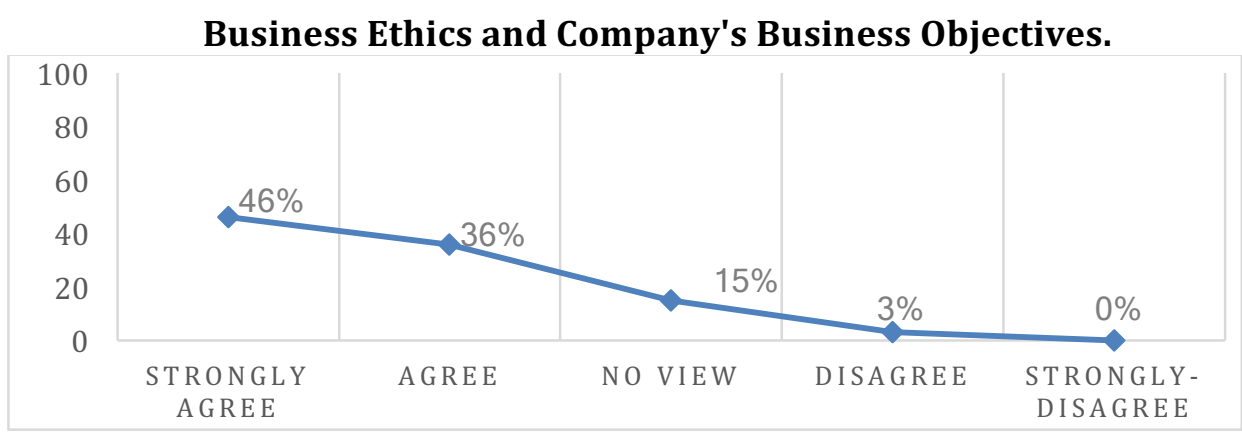

Fig. (9): Statement 9: on Your Board considers Business Ethics when setting the Company's Business Objectives.

Statement (10) on the maximization of shareholder's wealth shows that $(61 \%)$ of the respondents strongly agree that maximising shareholders' wealth is the focal point of the corporate governance practices of their companies, and (32\%) of them agreed with the statement. Only (6\%) had no-view and just 1\% disagree and none of the respondents strongly disagree with statement 10, which is shown in (Fig.10) below. This result supports the literature that most of the Business organisation see the Anglo-American model of corporate governance as the primary way of creating shareholders wealth. However, the result also indicated that many companies are considering other issues such as business ethics, corporate social responsibility (CSR) and stakeholder issues. The Combined Code provisions provided companies and their boards with what they need to do to practice good corporate governance. The board should be independent of management, and there should be independent directors on the board (NEDs). The Combined Code (2003) stats that: "The board should include a balance of executive and non-executive directors (and in particular independent non-executive directors) such that no individual or small group of individuals can dominate the board's decision making." (A.3, 2003, FRC, 2016) 


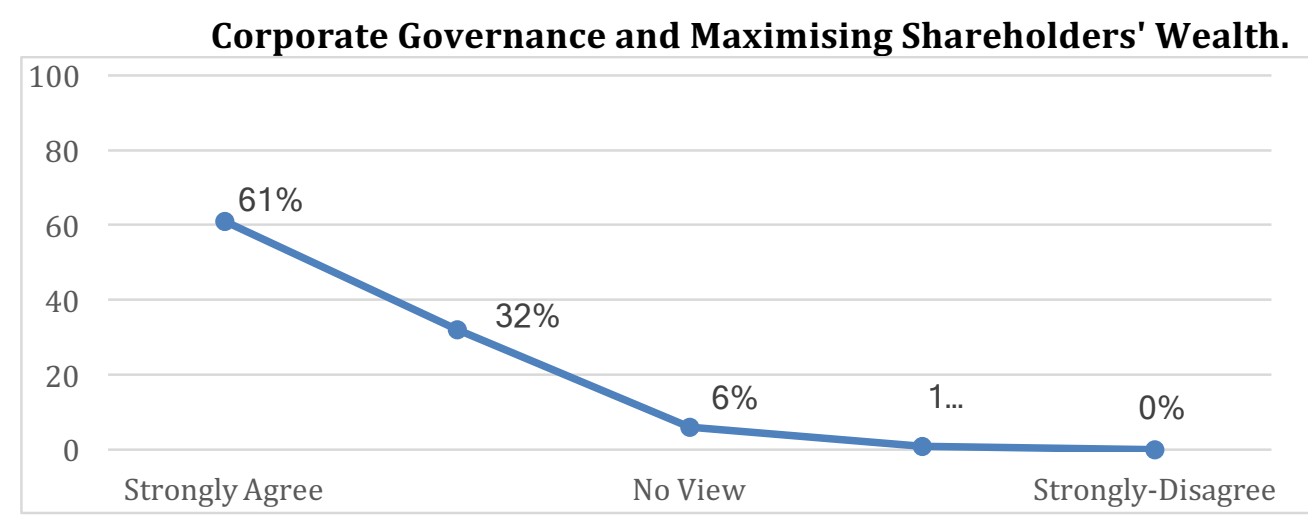

Fig. (10): Statement 10: on your organisation's corporate governance practices focus on meeting the business objective of maximising shareholders' wealth.

Although most of the companies in this survey have organizational codes and ethical values, in practice this is not so as companies still see shareholders' interests as the main reason for running the business. We can also acknowledge that without maximizing shareholders' wealth, the company may go out of business with operating losses that may result in merger and takeover. With the possible loss of jobs which may affect some stakeholders of the company as well, (e.g., employees, customers, suppliers, the general communities).

This statement (11) was about reliable and effective corporate governance regulation if companies are to meet the interest of their shareholdership and the needs of their stakeholdership, which will contribute, to good corporate governance in the banking and financial sectors. The results of the survey shown in Fig. (11) below shows that $70 \%$ of the respondents strongly agree and $20 \%$ agree that valid and reliable corporate governance is required in the banking and financial sectors to avoid or prevent the banking and financial meltdown of 2008 - 2011. Fig. (11) Also shows that $8 \%$ of the respondents had no view while $2 \%$ disagree with statement 11 . The collapsed of Northern Rock Bank in the UK $(2008 / 2009)$ led to the global financial meltdown of 2009/2011 and show the weakness of the corporate governance system in guiding boards of directors in making business decisions that meet the shareholdership and stakeholdership of the companies. Since the financial meltdown, there has been an improvement in the development of ethical corporate governance in both developed and developing countries. In the UK for example, the Financial Reporting Council (FRC) has carried out a review of the UK corporate governance codes in 2012, 2014 and 2016 resulting in the current UK Corporate Governance Code. As indicated on (page 4) of this study other reviews and update on corporate governance system have been carried out. Research on corporate governance is on the upsurge in areas of policy and development.

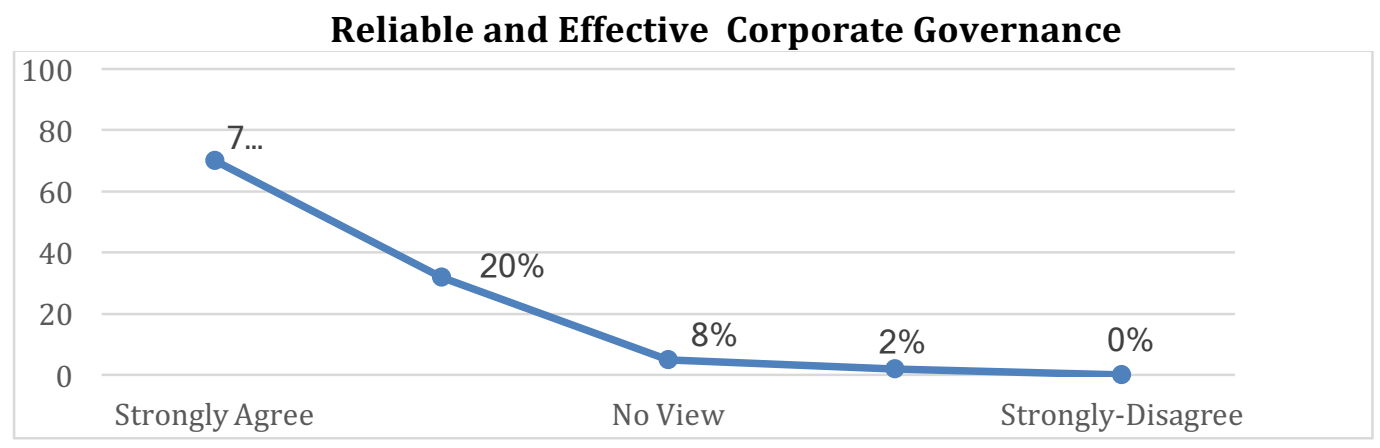

Fig. (11): Statement 11: on the financial meltdown indicates that reliable and effective corporate governance is required if companies are to meet their shareholders' needs. 
The final survey questionnaire statement (12) with the results shown in (Fig.12) below, was the issues of taking the needs of stakeholdership groups into consideration by public corporations, which in turn contribute to meeting the interest of the shareholdership in the long-run. The results above show that $60 \%$ of the respondents in the survey strongly-agree, with $30 \%$ agreeing with the statement. However, while most of the respondents, $(60 \%+30 \%)$ representing $90 \%$ of the respondents strongly agree or agree, $5 \%$ of the respondents had noview, 3\% disagree and $2 \%$ strongly disagree. In the literature, the issue of companies contributing to the needs of their stakeholdership groups through corporate social responsibility (CSR) is essential to the growth of shareholdership wealth. Some research in this areas shows the importance of engagement with stakeholders through corporate social responsibility, business ethics and environmental responsibility. Through community supports companies can contribute to the needs of the local communities where they carry out their businesses. “Good business ethics do good business" (Friedman, 1970).

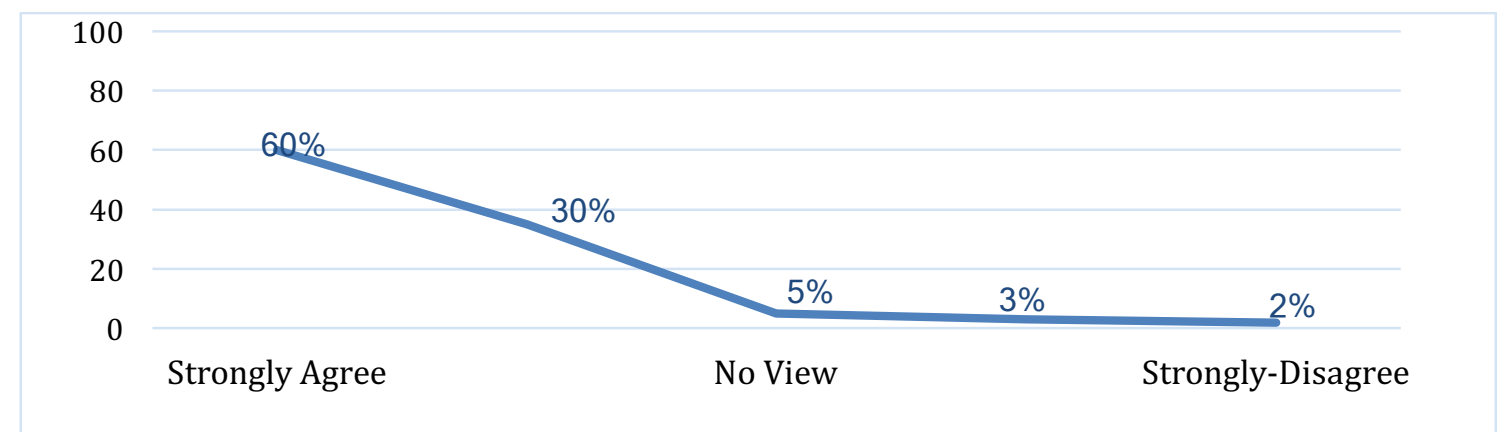

Fig. (12); Statement 12: Companies that incorporate the needs of their broader stakeholder groups can attract and create wealth for their shareholders in the long-term.

According to (Browne and Nuttall, 2013), executives need a new approach to engaging the external environment. We believe that the best one is to integrate external engagement deeply into their business decision-making at every level of the company. Are companies doing well at external engagement? "Properly understood, external engagement means the efforts a company makes to manage its relationship with the external world. In practice, however, most companies have relied on three tools for external engagement: a full-time CSR team in the head office, some high-profile (but relatively cheap) initiatives, and a glossy annual review of progress." (Browne and Nuttall, 2013:3).

\section{CATEGORIES FROM THE RESULTS OF DATA ANALYSIS}

The analysis of data from the 12 survey statements resulted in 8 main categories of ethical corporate governance issues, see (Fig.13) below for data categorisation on Shareholdership Model and (Fig.14) on Stakeholdership Model. The bar charts constructed to help further an understanding of the data. 


\section{The Substantive Theory on Shareholdership Model of Ethical Corporate Governance}

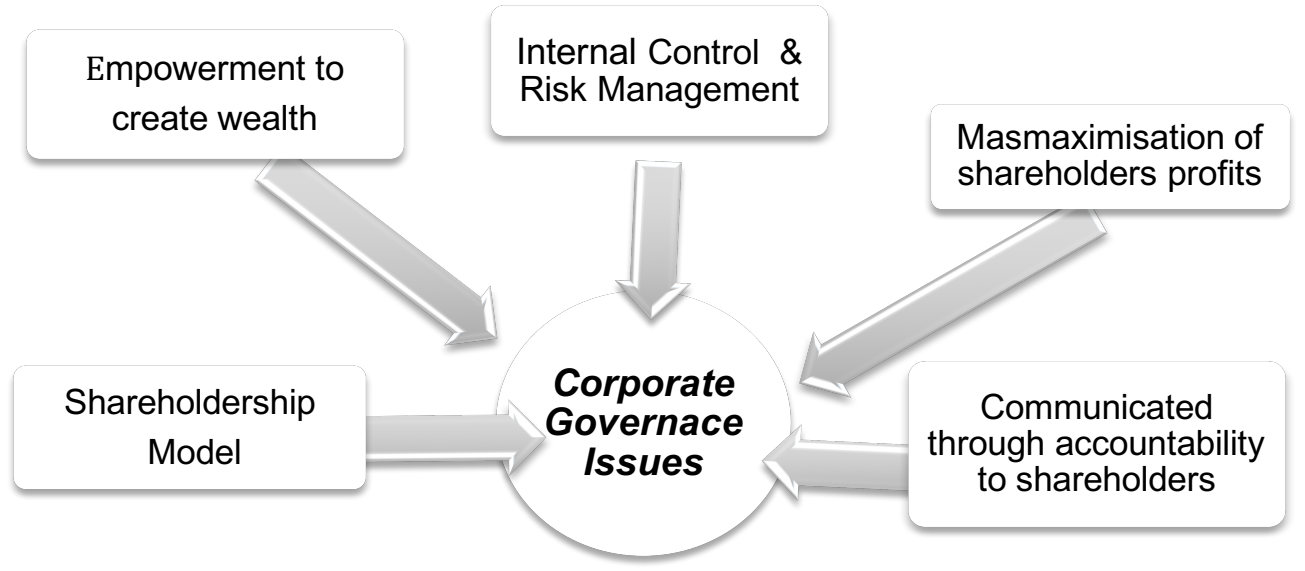

Fig. (13): On Shareholdership Model - empowerment to create wealth communicated through accountability to shareholders about shareholder theory.

The substantive theory is developed around the ethical issues of corporate governance in the decision-making process of corporate governance practices of boards of directors of public limited companies.

The substantive theory developed on corporate governance can be stated as:

(i) On Shareholdership Model - empowerment to create wealth communicated through accountability to shareholders about shareholder theory.

(ii) On Stakeholdership Model-the expectation to shared values communicated through justification to stakeholders about stakeholder theory.

\section{The Substantive Theory on Stakeholdership Model of Ethical Corporate Governance}

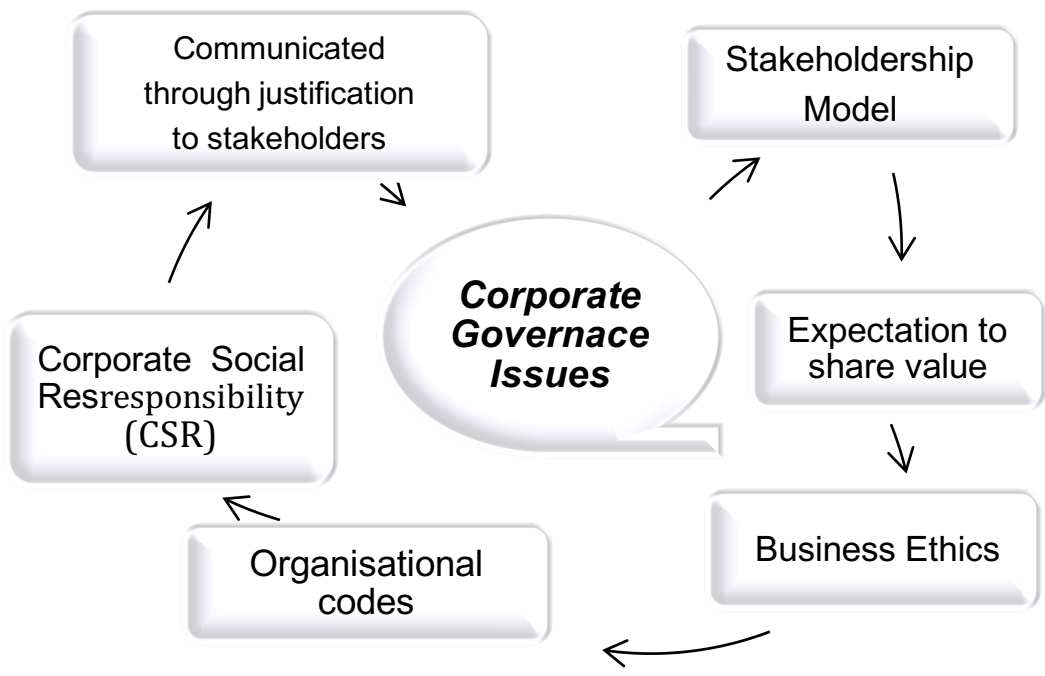

Fig. (14): On Stakeholdership Model - the expectation to shared values communicated through justification to stakeholders about stakeholder theory.

The article presents an understanding of the debut and knowledge on ethical issues on corporate governance and how to help the Board of Directors on decision making in meeting the needs and expectations of the company's different shareholdership groups and stakeholdership groups. 


\section{DISCUSSION OF THE FINDINGS}

The findings from this study on expectations, perceptions behaviuor and accountability of the boards of directors towards their shareholdership and stakeholdership groups, show that when it comes to the issues of shareholders, most of the respondents supported the AngloAmerican systems of corporate governance. However, as explained by the models developed from the analysis of data collected through survey questionnaire there is the recognition that boards of directors are taking the issues of their companies' stakeholdership groups into consideration when setting their business objectives. In term of ethical corporate governance, through organisations code of conduct and corporate social responsibility policies, companies now reach out to their broader stakeholdership groups through engagement with stakeholders. Such engagement is ongoing with shareholders groups through boards accountability to shareholdership and expectations from stakeholdership.In general, the tables and charts developed from the analysis of the results of the survey questionnaire were used as models for analysing the survey results. The tables and diagrams help further our understanding of the views that the shareholders model of corporate governance is still the best way of managing the affairs of corporations and provide the platform for boards to meet the business objectives of maximising the shareholder's wealth and consider the stakeholder's needs. As could be seen from the tables and models most of the respondents agree that their boards of directors focus on the categories identified from the results of the analysis, (see Fig. 13 and Fig. 14). It enables them to manage the affairs of the company in compliance with the New UK Corporate Governance Code.Business Ethics or Organisational Codes help companies with maintaining their reputations and corporate values or brands. The Substantive Theory from data analysis through its coding methods, open coding, axial coding and selective coding.

\section{CONCLUSION}

This study provided an assessment of the effectiveness of ethical corporate governance practices of the boards of directors of ftse- 100 companies as represented by the views of their company secretaries. company secretaries play a significant role in the corporate governance practices of their companies by advising the boards, board committees and individual directors and management compliance with the combined code and uk corporate governance. company secretaries also play a significant role in risk management of their organisations. it is their role to make sure that the boards and individual directors carry out their duties and responsibilities as specified in the combined code and company law regulations. the article illustrated and throw light on the effectiveness of ethical corporate governance in corporate decision making. impact of the combined code provisions on the boardroom's decision-making process and boards' effectiveness. This article shows that integrating external engagement is a reality for active corporate governance policies. We set out to answer three questions. Are companies doing well at external engagement? Where might they be going wrong? How can they do better? The answers to these questions result to ethical corporate governance practices which benefit both shareholdership and stakeholdership group of corporations. 


\section{References}

Abor, J. (2007). Corporate Governance and Financing Decisions of Ghanaian Listed Firms. Corporate Governance: The International Journal of Business in Society. 7(1), 83 -92.

Baiman, S. (1990). Agency Research in Managerial Accounting: A Second Look. Accounting Organizations and Society $_{2}$ 15(4), 341-37.

Bar H., (2017). Board of Directors Proper Conduct of Banking Business Directive No. 301. Bank of Israel Banking Supervision Department

Policy.http://www.boi.org.il/en/BankingSupervision/LettersAndCircularsSupervisorOfBanks

Berle, A.A. and Means, G.C. (1932). The Modern Corporation and Private Property. New York: Macmillan.

Blair, M. M. (1995). Ownership and Control Rethinking Corporate Governance for the Twenty-first Century. The Brookings Institute Washington, D.C.

Browne J. and Nuttall R. (2013). Beyond Corporate Social Responsibility: CSR Integrated external engagement: Strategy Practice: Retrieved from (http://www.mckeinsey.com/en/client service/strategy.aspx)

Cadbury Report, (1992). The Cadbury Committee Report - European Corporate Governance Institute. http://www.ecgi.org/codes/documents/cadbury.pdf_br

Cadbury, A. (2002). Corporate Governance and Chairmanship: A Personal View, Oxford University Press, Oxford. Charkham, J. (1989). Corporate Governance and Market for Control of Companies, Bank of England Panel Paper No.25, London: Bank of England.

Charmaz, K. (2000). Grounded Theory: Objectivist and Constructivist Methods, in N.K. Denzin and Y.S. Lincoln (eds), Handbook of Qualitative Research, 2nd, Thousand Oaks, CA: Sage. Pp. 509-536.

Charmaz, K. (2014). Constructing Grounded Theory $2^{\text {nd }}$ Edition, SAGE Publications Ltd London. UK, www.sagepub.co.uk/iqm

Chowdhury, S. I., Farhana Ferdous, F., Omar, F. (2018). The Linkage between Corporate Governance and Financial Performance in an Emerging Economy, International Journal of Engineering and Applied Sciences (IJEAS), 5(4),

Retrieved from https://en.wikipedia.org/wiki/Friedman doctrine

Combined Code, (2003). The Combined Code on Corporate Governance. http://www.ecgi.org/codes/documents/combined_code_final.pdf

Cook, J. and Deakin, S. (1999). Empirical Evidence and Corporate Governance Control, ESRC Centre for Business Research, University of Cambridge.

Davis, E. P., (2000). Institutional Investor and Corporate Governance, Brunel University, Uxbridge Middlesex UK.

Dalton, D., Daily, C., Certo, T., and Roengpitya, R. (2001). Meta-Analyses of Financial Performance and Equity: Fusion or Confusion? Academy of Management Journal, 46: pp. 13-26.

Denzin, N. and Lincoln, Y. S. (2002). The Art and Politics of Interpretation, in N. K. Denzin and Y. S. Lincoln (Eds.), Handbook of Qualitative Research. Thousand Oaks, CA: SAGE Publications. pp. 550- 515.

Denzin, N. and Lincoln, Y. S. 2013. (Eds.) The Landscape of Qualitative Research'. The SAGE 'Handbook of Qualitative Research'. 4th Edition. Thousand Oaks, CA: SAGE Publications. http://www.sagepub.com

Evans, S. C., (2016). The Role of the General Counsel in Corporate Strategy. ACC Association of Corporate Counsel, National Capital Region Pennsylvania Avenue NW Washington, DC.

Fama, E., and Jensen, M. C. (1983a). Separation of Ownership and Control. Journal of Law and Economics, 26: pp. 301-326.

Fama, E., and Jensen, M. C. (1983b). Agency Problems and Residual Claims,' Journal of Law and Economics, 26: pp. 327-352.

Fera, N. (1997). Using Shareholder Value to Evaluate Strategic Choices. Management Accounting (USA), $79,47$.

FRC, (2016). UK Corporate Governance Code. (C) The Financial Reporting Council FRC, London.www.frc.org.uk

FRC, (2014). UK Corporate Governance Code. (C) The Financial Reporting Council FRC. London. www.frc.org.uk

Freeman, E. (1984). Strategic Management: A Stakeholder Approach, Boston: Pitman Press.

Friedman, M. (1970).The Social Responsibility of Business is to Increase its Profits - the New York Times Magazine. 
Nwanji, T. I., Howell, K. E., Faye, S., Agba, D. Z., Adewara, S. O., Lawal, A. I., Otekunrin, A. O., Awonusi, F. D., \& Eluyela, D. F. (2019). Assessment of the Effectiveness of Ethical Corporate Governance in Corporate Decision-Making: A Grounded Theory Approach. Archives of Business Research, $7(1), 147-168$.

Green R. M. (1994). The Ethical Manager; A New Method for Business Ethics. Published by Macmillan Publishing Company New York

Greenwood, R. M. (2000) The Study of Business Ethics: A Case for Dr Seuss, Business Ethics: A European Review, 9(3), pp. $155-162$.

Guardian Newspaper (1997) Business Leadership and Ethics, The Director

Glaser, B.G. (1978). Theoretical Sensitivity. Mill Valley, C.A: Sociology Press.

Glaser, B. G. (1992). Basics of Grounded Theory Analysis. Mill Valley, CA: Sociology Press

(http://www.groundedtheory.com).

Glaser, B.G. (1998). Doing Grounded Theory: Issues and Discussions. Mill Valley, CA: Sociology Press.

Glaser, B. and Strauss, A. (1967). The Discovery of Grounded Theory, New York: Aldine de Gruyter.

Greenbury Report, (1995). On Directors' Remuneration: Code of practice for UK PLCs. The Confederation of British Industry (CBI).

Goulding, C. (2002). Grounded Theory: A Practical Guide to Management, Business and Marking Researcher. SAGE Publications, London.

E.G., and Lincoln, Y.S. (2002). Competing Paradigms in Qualitative Research. In N.K. Denzin and Y.S. Lincoln (Eds.), Handbook of Qualitative Research (p. 105-117). Thousand Oaks, CA: Sage Publications.

Hampel, Committee Report (1998). Corporate Governance Code UK for the DTI London (http://www.dti.gov.uk)

Harvey, C. R. (2012). Demand shock: An event that affects the demand for goods and services in an economy.Retrieved from http://financial dictionary.thefreedictionary.com/Demand+shock

Higgs Report, (2003). Review of the Role and Effectiveness of Non-Executive Directors Department of Trade and Industry, London.

Howell, K. E. and Letza, S. (2000). Virtue, the Categorical Imperative and the Civic Constitution: Defining Corporate Governance. The Journal of Interdisciplinary Economics Vol. 11, No 1, pp. 95-1.

Howell, K. E. (2000). Discovering the Limits of European Integration, Applying Grounded Theory. Nova Science Publishers Inc. Huntington.

Howell, K. E. (2003). Integrating European Financial Services: Developing Substantive Theory. Current Politics and

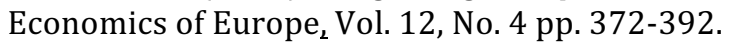

Howell, K. E. (2013). An Introduction to the Philosophy of Methodology SAGE Publication London.

Hutton, W. (1995). The State We're In: London: Cape. 4, pp. 372-392.

GCGC. (2016). Good Corporate Governance Code (GCGC) (C) The Financial Reporting Council Limited. The Financial Reporting Council Limited Registered in England number 2486368. Registered London Wall, London EC2Y 5AS.

ICSA, (2012). Good Governance Practices the Institute of Chartered Secretaries and Administrators (ICSA) London, Volume 5, Issue 1, Fall ISSN 1727-9232 Pages 9-23.

Jalan K., (2006). Role of Financial Intermediaries in The 21 ${ }^{\text {st }}$ Century, Occasional Papers. ICFAI Business School India. Retrieved from http://www.indianmba.com/occasional_papers/op125/op125.html

Jensen, M. C. And Meckling, W. H. (1976). Theory of the firm: Managerial behaviour, Agency costs and ownership structure, Journal of Financial Economics, pp. 305 - 360.

Jensen, M. C. (1993a). The Modern Industrial Revolution, Exit, and the Failure of Internal Control Systems, Journal of Finance 48: pp. 831-80.

Jensen, M. C. (2001).Value Maximization, Stakeholder Theory, and The Corporate Objectives Function. The Monitor Group and Harvard Business School

John, L. (2013). Towards a Grounded Theory Methodology: Reflections for Management Scholars. Irish Journal of Management.

Kay, J. and Silberston, A. (1995). Corporate Governance, National Institute 97. 
Keasey, K., Thompson, S. and Wright, M. (1997). Introduction: The Corporate Governance Problem - Competing Diagnoses and solutions, In Keasey, K. Thompson, S. and Wright, M. (Eds) Corporate Governance: Economic and Financial Issues, University Oxford, pp. 1-17

Kirkbride, J. and Letza, S. (2005a). Can the Non-Executive Director Be an Effective Gatekeeper? The Possible Development of a Legal Framework of Accountability. Corporate Governance: An International Review, Vol. 13, No. 4, pp. 542-550, Available at SSRN: https://ssrn.com/abstract=754292

Kirkbride, J., James, A. and Letza, S. (2005b). Does the criminal law have a role in the corporate setting? International Journal of Business Governance and Ethics, Vol. 1, No. 4 pp. 259-276.

Letza, S.; Kirkbride, J. and Sun, X. (2004). Shareholding versus Stakeholding: A Critical Review of Corporate Governance. Corporate Governance: An International Review, Vol. 12, No. 3, pp. 242-262.

Liao, C. 2010. Rethinking U.S. Corporate Governance Reform In The Wake of the Global Financial Crisis.https://open.library.ubc.ca/collections/ubctheses

Locke, K. (2001). Grounded Theory in Management Research: SAGE

Publishers.http://www.sxf.uevora.pt/wpcontent/uploads/2013/03/Lock20011.pdf

Manne, H.G. (1965). Mergers and the Market for Corporate Control, Journal of Political Economy Vol.(75): 110-26

MENA Report, (2016). Luxembourg : Publication of Book Studies 104 -Employment, Wages and Prices: How Did Firms Adjust during the Economic and Financial Crisis: Evidence From a Survey of Luxembourg Firms.MENA Report, Alabama (London) Ltd., n/a.

Mitlak, A. S. N. (2016). An investigation into the effect of corporate governance on audit quality in developing markets: Evidence from Jordan. Doctoral thesis, Durham University UK. www.durham.ac.uk

Myners Report, (2001). Institutional Investment in the UK - Best Practice Approach to Investment Decision Making for Pension Funds. HR Treasury UK

Nwagbara, U. and Ugwoji, C. A. (2015). Corporate Governance, CSR Reporting and Accountability: The Case of Nigeria. Economic Insights - Trends and Challenges.

Nwanji, T. I. and Howell, K. E. (2005). The Stakeholder theory in the Modern Global Business Environment. International Journal of Applied Institutional Governance, Vol.1, (1), pp. 1-12.

Nwanji, T.I. and Howell, K. E. (2007b). Shareholdership, Stakeholdership and the Modern Global Business Environment: A Survey of the Literature.Journal of Interdisciplinary Economics.Vol.18 No 4 pp. 347-361 ISBN 0260-1079 SAGE Publication Journal.

Nwanji, T.I. (2016). Ethical Perspectives on Corporate Governance. In: Howell K., Sorour M. (eds) Corporate Governance in Africa. Palgrave Macmillan, London.

Nwanji, T.I., Howell, K. E., Alao, E. M., Lawal, A. I. and Faye, Sainey, (2017). Telling the Truth and Ethical

Perspectives in Corporate Decision-Making. Journal of Management and Corporate Governance, Vol.9, No.3, Pp 118

OECD, (2004). OECD Principles of Corporate Governance, OECD, Paris. Ret. from(http://www.oecd.org/social/poverty/28658158.pdf_br)

Ogbu, U. (2015). An Investigation into the Effect of Corporate Governance Regulation on Developing Countries Stock Exchange - Comparative Study of Nigerian Stock Exchange Market) PhD Thesis on Corporate Governance, St Clements University.

Patel, M. (2018). Corporate Governance and Financial Performance in an Emerging Economy Context: Evidence from Pakistan's Food, Personal Care and Cement Sectors. South Asian Journal of Management, Vol.25(1).

Phillips, R. (2003). Stakeholder Theory and Organizational Ethics. Published by Berrett-Koehler Publishers, Inc. San Francisco.

PWC, (2003). Shareholders' Questions: Questions that may be asked at 2003 Shareholders' Meetings. PricewaterhouseCoopers LLP.

Roy, M.J. (2015). Characterising Performance Evaluation Systems for Corporate Directors.Presented at European Conference on Management, Leadership and Governance, 386.

Sephered, B. (1999). The Growing Clout of Independent Directors, Global Finance, 13(6), 52-53.

Shleifer, A. and Vishny, R. (1997). A Survey of Corporate Governance, Journal of Finance, 8(2), 737-783. 
Nwanji, T. I., Howell, K. E., Faye, S., Agba, D. Z., Adewara, S. O., Lawal, A. I., Otekunrin, A. O., Awonusi, F. D., \& Eluyela, D. F. (2019). Assessment of the Effectiveness of Ethical Corporate Governance in Corporate Decision-Making: A Grounded Theory Approach. Archives of Business Research, 7(1), 147-168.

Smith, R. (2003). Audit Committees Combined Code Guidance. A Report and Proposed Guidance by an FRC Appointed Group. Financial Reporting Council. (www.frc.org.uk/publication).

Sternberg, E. (2001). The Stakeholder Concept: A Mistaken Doctrine Foundation for Business Responsibilities.

Sternberg, E. (2004). Corporate Governance: Accountability in the Marketplace, (2 ${ }^{\text {nd }}$ Edition), IEA, The Institute of Economic Affairs, London.

Strauss, A. and Corbin, J. (1998). Basics of Qualitative Research: Techniques and Procedures for Developing Ground Theory $2^{\text {nd }}$ Edn. Oaks CA.

Strauss, A. and Corbin, J. (2007). Basics of Qualitative Research: Techniques and Procedures for Developing Ground Theory, 2nd Edn. Thousand, Oaks CA: Sage. The USA.

Strauss, A. L. (1987). Qualitative Analysis for Social Scientists. Cambridge University Press.

Stoney, C. and Winstanley, D. (2001). Stakeholding: Confusion or Utopian? Mapping the Conceptual Terrain. Journal of Management Studies, 38:5,pp. 603-626.

Sun, X. (2002). Rethinking Corporate Governance A Processual Approach. PhD Thesis of Leeds Metropolitan University.

Sun, X., Letza, S. and Chia, R. (2002). Governance Versus Governing: Philosophical Issues Underpinning Corporate Governance. Leeds Metropolitan University.

Sykes, A. (1994). Proposals for Internationally Competitive Corporate Governance Britain and America, Corporate Governance, pp. 187-95.

Turnbull Report, (2005). Internal Control and Risk Management: Developing Roles of Internal Audit http://Review_of_the_role_and_effectiveness_of_non-executive_directors_br

Urquhart C. (2013). Grounded Theory for Qualitative Research: A Practical Guide. SAGE Publications Ltd London.

Volpin, P. and Clare, A. (2015). The Great Governance Debate - Towards a Good Governance Index for Listed Companies. Institute of Directors in association with Cass Business School London.http://www.zyen.com/Research/Research/IOD\%20Good\%20Governance\%20Report.pdf

Walker Review, (2009). A Review of Corporate Governance in UK Banks and other Financial Industry Entities Final Recommendations.Retrieved from http:/www.hm-treasury.gov.uk/d/walke

Yahaya, L. A. (2016). Influence of Maternal Acceptance on Self-esteem as Expressed by Secondary School Students in Kwara State.Nigerian Journal of Guidance and Counsel.

Zajac, E. J. and Westphal, J. D. (1996a). Who Shall Succeed? How CEO/Board Preferences and Power Affect the Choice of a New OECs', Academy of Management Journal, Vol. 39 (1), pp. 64-90.

Zajac, E. J. and Westphal, J.D. (1996b). Director Reputation, CEO-Board Power, 507-29. and the Dynamics of Board Interlocks, Administrative Science Quarterly, 41. 